\title{
Effects of primovaccination and booster vaccination on serum cortisol and humoral immune response in cattle
}

\author{
Luis S. L. S. Reis ${ }^{1}$, Paulo E. Pardo ${ }^{2}$, Neusa M. Frazatti-Gallina ${ }^{3}$, Rosana L. Paoli ${ }^{3}$, Eunice Oba ${ }^{4}$, \\ Sergio N. Kronka ${ }^{5}$, Aline S. Camargos ${ }^{4}$ \\ ${ }^{1}$ Department of Bromatology, Food and Animal Nutrition, Universidade de Santo Amaro, São Paulo, Brazil \\ ${ }^{2}$ Department of Medical Clinic, Universidade do Oeste Paulista, Presidente Prudente, Brazil \\ ${ }^{3}$ Section of Rabies of Instituto Butantan, São Paulo, Brazil \\ ${ }^{4}$ Department of Animal Reproduction and Veterinary Radiology, Universidade Estadual Paulista, Faculdade de Medicina Veterinária \\ e Zootecnia, Campus Botucatu, Brazil \\ ${ }^{5}$ Universidade Estadual Paulista, Faculdade de Ciências Agrárias e Veterinárias de Jaboticabal, Campus Jaboticabal, Brazil \\ Email: reis.1sls@gmail.com
}

Received 1 March 2013; revised 6 April 2013; accepted 10 May 2013

Copyright (C) 2013 Luis S. L. S. Reis et al. This is an open access article distributed under the Creative Commons Attribution License, which permits unrestricted use, distribution, and reproduction in any medium, provided the original work is properly cited.

\section{ABSTRACT}

The objective of this study was to evaluate the effect of one or two doses of the anti-rabies vaccination on the serum concentration of cortisol and the humoral immune response in cattle as well as the correlation between serum cortisol concentrations and the titers of rabies-neutralizing antibodies. Nelore cattle were randomly assigned to one of three groups, which were vaccinated with one dose of rabies vaccine (group GVSR, N = 15), two doses of rabies vaccine (group GVR, $N=15$ ) or were not vaccinated (group Gc, $\mathbf{N}=$ 15). A commercial liquid inactivated rabies vaccine was used. The stressors imposed on the cattle were vaccination, corral handling and the presence of people. Blood samples were collected on days 0,30 and 60 post-vaccination. Serum cortisol concentrations were determined using a solid-phase radioimmunoassay, and rabies antibody titers were determined using a serum neutralization test with $\mathrm{BHK}_{21}$ cells (RFFIT). Both serum cortisol concentrations and antibody titers increased after the second (booster) vaccination $(P<0.05)$. In all the groups, the serum cortisol concentrations increased after the cattle were handled in the corral $(P<0.05)$. No correlation was observed between the serum cortisol concentrations and the antibody titers with any treatment or on any observation day. In conclusion, booster vaccination is indispensable for primovaccinated cattle in achieving high and protective levels of rabies antibodies. Although booster vaccination and frequent cattle handling in corrals are stressors, the response is not strong enough to cause immunosuppression in cattle.
Keywords: Cattle; Stress; Stressor; Cortisol; Rabies Vaccination; Antibody

\section{INTRODUCTION}

Rabies is a viral infectious disease of the central nervous system of mammals that is caused by a neurotropic virus of the Rhabdoviridae family and the Lyssavirus genus $[1,2]$. The hematophagous bat Desmodusrotundus is the main transmitter of this disease to cattle in Latin America [3]. This disorder is considered one of the world's most important types of zoonosis because it presents fatal encephalitis that can affect all mammals without treatment and it has a worldwide distribution [1,2]. In Brazil, rabies is estimated to cause the annual loss of approximately 850,000 heads of cattle, which is approximately equivalent to 17 million US dollars [4].

Constant and periodic mass cattle vaccination is the best means of protecting against and controlling this disease because vaccination is effective, low cost and reduces economic losses $[5,6]$. However, during vaccinetion, it may necessary to submit the animals to various stressors, such as handling, i.e., moving them to a corral that is a new and unknown environment for the animals $[5,6]$, the presence of people and people yelling $[7,8]$ and the pain caused by vaccine application [9]. These stressors activate the hypothalamic-pituitary-adrenal (HPA) axis and adrenal glands to stimulate produce and secrete cortisol, epinephrine and norepinephrine hormones [6, $10,11]$, and a high elevation in cortisol bloodstream is associated with immunosuppressive effects [12] and can cause the reduced production of anti-rabies antibodies in animals as related by Ciuchini et al. [13], Queiroz da 
Silva et al. [14] and Albas et al. [15]. Moreover, Giometti et al. [16] reported that 60 days after the rabies vaccination there were more than $50 \%$ of animals with antibody titers below the level considered protective.

Although the low humoral immune response after rabies vaccination in cattle is concerning, there are few studies that have evaluated the immunosuppressive effect of stress in cattle previously vaccinated against rabies. The objective of the present study was to evaluate the effect of vaccination stress with one or two doses of rabies vaccine on the humoral immune response.

\section{MATERIAL AND METHODS}

\subsection{Experimental Location}

The experiment was conducted during the spring season (September to October) in the city of Lutetia-SP, Brazil. The city has a tropical climate, which is characterized by a rainy season from October to April and a dry seasonfrom May to September, with average annual rainfall of $1300 \mathrm{~mm}$, humidity relative air of $64 \%$, an average temperature of $25^{\circ} \mathrm{C}$ and an altitude of $602 \mathrm{~m}$. Nelore cattle are highly adapted to these climatic conditions.

\subsection{Animals}

Forty-five crossbred Nelorebulls (Bostaurusindicus), approximately 12 months of age, fed Brachiariadecumbens in an extensive grazing system supplemented with a commercial mineral mixture adlibitum were used. These animals were randomly divided into 3 groups (15 animals/ group): a control group ( $\mathrm{Gc}$ ) in which the animals were not vaccinated and the other two groups in which the cattle were immunized with one dose of rabies vaccine (primovaccination)on day zero (group GVSR) or two doses of vaccine on days 0 and 30 (GVR group).

\subsection{Rabies Vaccine}

A commercial liquid vaccine against rabies was used, which consisted of a suspension of fixed rabies PV virus (Pasteur virus) grown in a culture of BHK-21 cells, inactivated by $\beta$-propiolactone, adsorbed in adjuvant and preserved with thimerosal 1:10,000. The vaccine had antigenic values within the recommended parameters for an efficient immune response and was duly approved by the Ministry of Agriculture, Livestock and Supply (MAPA) of Brazil.

\subsection{Stressors}

The stress or simposed on the cattle were all the result of the immunization procedure, which included carrying the animals from the pasture to the corral, the actual vaccination, handling in the corral and the presence of people during handling.

\subsection{Bovine Blood Sample Collection}

Blood samples were collected on days zero, 30 and 60 . For blood collection, the animals were taken to the corral in the morning and immobilized in a stem-type Brete chute, and $10 \mathrm{ml}$ of blood from each animal was collected by puncture of the jugular vein. The blood was collected into vacuum tubes without anticoagulant. The blood samples were transported to the laboratory in a cooler with ice. After centrifugation at $2500 \mathrm{rpm}$ for 10 min, the serum samples were packaged and stored at $-20^{\circ} \mathrm{C}$ for later determination of the serum cortisol concentration and the presence of rabies-neutralizing antibodies.

\subsection{Titration of Anti-rabies}

The individual titers of neutralizing antibodies were determined via serum neutralization in BHK21 clone 13 cells from the Rage cell bank section of the Butantan Institute. This test was developed based on the "Rapid Fluorescent Focus Inhibition Test" (RFFIT) [17] and "Fluorescent Inhibition Microtest" (FIMT) [18]. CVS11 virus and the $2^{\text {nd }}$ International Standard for anti-rabies serum were used as controls.

\subsection{Determination of Serum Cortisol}

Serumcortisol concentrations were determined using a radioimmunoassay solid phase commercial kit (DPC-Diagnostic Products Corporation, USA) and counted in a Cobra Auto-Gamma Count II counter.

\subsection{Statistical Analysis}

The data were analyzed according to a split plotexperiment with two groups (main treatments) and two days of collection (secondary treatments) in a completely randomized design with 15 replications. For the statistical analysis of serumcortisol concentrations, an analysis of variancevia an $\mathrm{F}$ test was used, and the means were compared using the Tukey test [19].

Neutralizing antibody antirabies titers displayed heterogeneity of variances due to the large variation inthe results of the GVRgro upon day 60 . For the homogenization of variance, the data were transformed to LN (SQRT $(\mathrm{X})$ ) values (logarithm of the square root of $X$ values).

The correlation coefficient(r) was used to evaluate the correlation between the serum cortisol and serum titers of anti-rabies data by different groups and the blood collection days. In all statistical analyses, the significance of the data was set to $5 \%$.

\section{RESULTS}

The cattle GVR group displayed a significant increase (P $<0.05$ ) in serum cortisol concentration after receiving 
the second rabies vaccination on day 30 compared with the Gc and GVSR groups (Figure 1). Moreover, the GVR group animals displayed a significant increase $(\mathrm{P}<$ 0.05 ) in serum cortisol concentration throughout the experimental period, whereas in the Gc and GVSR groups, the serum cortisol concentration increased significantly $(\mathrm{P}<0.05)$ only on day 60 .

The serum cortisol and antirabies antibody titers of the GVSR and GVR groups were not correlated $(\mathrm{P}>0.05)$ on days 30 and 60 (Table 1).

There was no significant difference $(\mathrm{P}>0.05)$ in the antirabies antibody titers between the GVSR and GVR groups on day 30 , but on day 60 of observation, there was a significant increase of antirabies antibody titers in the GVR group (Table 2).

\section{DISCUSSION}

The basal concentration of cortisol for Zebu cattle is 3.29 $\mathrm{mg} / \mathrm{dL}$ according to Aragon et al. [20] and Vásquez and Herreira [21]. Thus, the bovine serum cortisol concentrations of groups Gc, GVR and GVSR were within the basal concentration (Figure 1), indicating that the cattle were not stressed. Furthermore, the sera from all animals used in the experiment, which were collected before immunization against rabies, were not reactive to rabies, indicating that these animals had not been in contact with the rabies virus or the rabies vaccine before. Therefore, the variations observed in the serum cortisol concentrations and the anti-rabies neutralizing antibodies in the sera of the animals during the experimental period were exclusively induced by rabies vaccination.

The twice-consecutive handling of cattle in the corral with an interval of 30 days, whether administering a vaccine dose (primovaccination) or not, generated stress in the animals because the serum cortisol concentrations were similar $(\mathrm{P}<0.05)$ between the Gc and GVSR (Figure 1) groups as well as between day zero and day 30 of

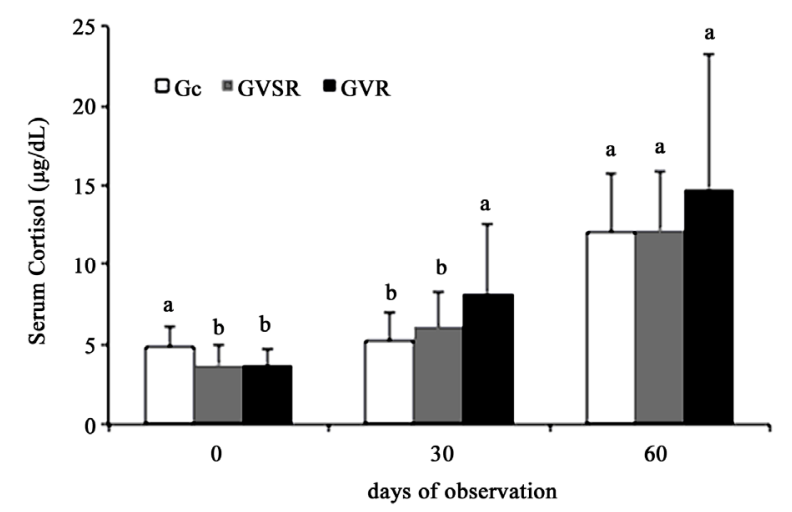

Figure 1. Effect of primovaccination against rabies (GVSR), booster application (GVR) and no vaccination (Gc) on the serum cortisol concentration in cattle. In the same groups, the means followed by the same letter did not differ according to the Tukey test $(\mathrm{P}>0.05)$. observation in these groups (Figure 2). However, frequent handling in the corral, e.g., more than two times, was stressful as indicated by the significant increase $(\mathrm{P}<$ $0.05)$ in serum cortisol concentrations on day 60 of observation (Figure 2). A similar phenomenon was observed by Reis et al. [22].

The booster vaccination was a stressor for the cattle.

Table 1. Values of the coefficients of linear correlations between the serum cortisol concentrations and the titers of antirabies antibodies by days of observation in cattle primovaccinated against rabies (GVSR) and in cattle who received a booster dose (GVR).

\begin{tabular}{ccc}
\hline \multirow{2}{*}{$\begin{array}{c}\text { Cattle } \\
\text { groups }\end{array}$} & \multicolumn{2}{c}{$\begin{array}{c}\text { Values of correlations between serum cortisol } \\
\text { concentrations and titers of antirabies antibodies }\end{array}$} \\
\cline { 2 - 3 } & \multicolumn{2}{c}{ Days of observation } \\
\hline GVSR & $-0.22^{\mathrm{NS}}(\mathrm{P}>0.22)$ & 60 \\
GVR & $0.11^{\mathrm{NS}}(\mathrm{P}>0.70)$ & $0.13^{\mathrm{NS}}(\mathrm{P}>0.13)$ \\
\hline
\end{tabular}

NS: not significant.

Table 2. Means $( \pm \mathrm{sd})$ of titers of neutralizing antirabies antibodies of primovaccinated (GVSR) and booster vaccinated (GVR) cattle.

\begin{tabular}{|c|c|c|c|c|}
\hline \multirow{4}{*}{$\begin{array}{l}\text { Cattle } \\
\text { groups }\end{array}$} & \multicolumn{4}{|c|}{ Means of titers of antirabies antibodies (IU/mL) } \\
\hline & \multicolumn{4}{|c|}{ Days after vaccination } \\
\hline & \multicolumn{2}{|r|}{30} & \multicolumn{2}{|r|}{60} \\
\hline & $(\operatorname{LN}(\sqrt{x}))$ & Original dates & $(\operatorname{LN}(\sqrt{x}))$ & Original dates \\
\hline GVSR & $-0.938^{\mathrm{Aa}}$ & $0.09 \pm 0.09$ & $1.165^{\mathrm{Aa}}$ & $0.10 \pm 0.13$ \\
\hline GVR & $-1.198^{\mathrm{Ab}}$ & $0.15 \pm 0.24$ & $1.158^{\mathrm{Ba}}$ & $10.29 \pm 10.79$ \\
\hline
\end{tabular}

A, B: in each day, means of groups followed by the same capital letter did not differ $(\mathrm{P}>0.05)$; $\mathrm{a}, \mathrm{b}$ : in each group, means of days followed by the same lower case did not differ $(\mathrm{P}>0.05)$.

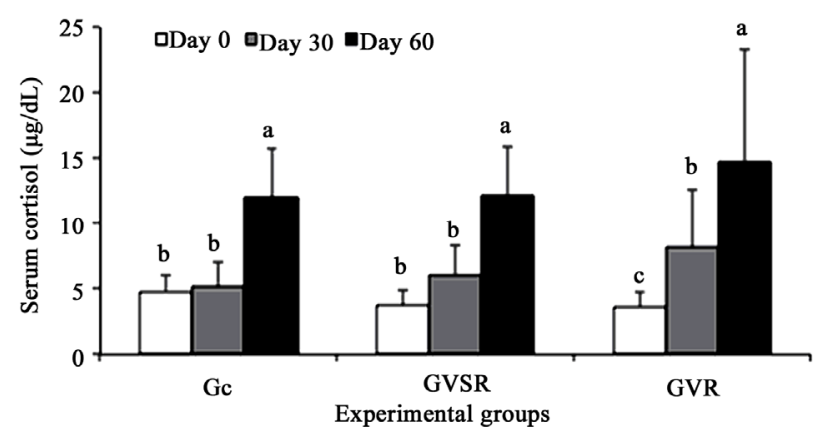

Figure 2. Effect of time of exposure to stressors on serum cortisol concentration of non-vaccination (Gc), rabies primovaccination (GVSR) and receipt of booster antirabies vaccine (GVR) in cattle. In the same group, the means followed by the same letter did not differ according to the Tukey test $(\mathrm{P}>0.05)$. 
The serum cortisol concentration of the GVR group significantly increased $(P>0.05)$ on day 30 (Figures 1 and 2) when these animals received the rabies vaccine booster dose.

The stress generated in the cattle by the booster vaccination may be associated with the frequent handling of the animals in the corral $[6,8,11,23]$ because the corral was a new and unfamiliar environment for the cattle [5, 24] and because the presence of strangers may cause stress $[8,24]$. In addition, the shouting and aggression displayed by humans [7] generates fear and pain in animals and activates the HPA axis, which elevates serum cortisol concentrations $[24,25]$.

Despite the booster vaccination and the frequent handling in the corral, the stress levels did not result in immuno suppression, as there was no significant correlation $(\mathrm{P}>0.05)$ between the titers of the anti-rabies antibodies and the bovine serum cortisol concentrations in the GVSR and GVR groups (Table 1). These results confirm the findings of Chacon and Lopez [26], who reported that cattle lymphocytes are not very sensitive to increased concentrations of steroids in the bloodstream.

Successful control of infectious diseases via vaccination is advantageous, and despite generating stress in common animals due to management in the corral and booster vaccinations, the strategy results in no immunosuppression. Cattle are often grazed in the corral as a component of conducting periodic vaccinations to control various infectious diseases, to control ectoparasites and endoparasites, and to perform other types of health management that are needed when raising cattle.

The World Health Organization (WHO) recommends a neutralizing anti-rabies antibody titer equal to or greater than 0.5 International Unit $/ \mathrm{mL}$ to protect humans from infection with the rabies virus. However, some authors theorize that this value is the minimum required for protection of cattle [16,27-31]. Thus, as seen in Table 2 , 30 days after the first vaccination against rabies, $100 \%$ of the animals in the GVSR and GVR group were still susceptible to contracting the rabies virus. These findings corroborate the results of Giometti et al. [16].

This low humoral immune response in cattle against rabies-primovaccinated cattle is not associated with immunosuppression due to the stress generated by the management of the cattle in the pen (Figure 1). There was no significant correlation between the anti-rabies antibody concentrations and the serum cortisol concentrations $(\mathrm{P}>0.05)$ (Table 1). Further studies should be conducted to elucidate the possible causes of this humoral immune response against rabies in cattle that were previously vaccinated against rabies.

In animals that received a booster dose (GVR group), the antibody titers were significantly increased $(\mathrm{P}<0.05)$ at day 60 , and $100 \%$ of the animals reached or surpassed the minimum titer of anti-rabies that is considered to be protective $(\geq 0.5 \mathrm{IU} / \mathrm{mL})$. These findings prove the need for the application of a booster vaccination for the control of rabies in cattle and confirms the findings of Rodrigues da Silva et al. [28], Queiroz da Silva et al. [14], Albas et al. [15], Giometti et al. [16] and Maria et al. [29], who showed that reinforcement immunization is required for animals that were previously vaccinated against rabies antibody titers to maintain high and persistent levels of antirabies antibodies.

\section{CONCLUSION}

The results of the present study indicated that frequent management in the corral and rabies booster vaccination stressed cattle, but this stress did not result in immunosuppressive effects. This study also proves that the use of a rabies vaccination booster for cattle produces high titers of anti-rabies antibodies.

\section{REFERENCES}

[1] Kobayashi, Y., Ogawa, A., Sato, G., Sato, T., Itou, T., Samara, S.I., Carvalho, A.A., Nociti, D.P., Ito, F.H. and Sakai, T. (2006) Geographical distribution of vampire batrelated cattle rabies in Brazil. Journal of Veterinary $\mathrm{Me}-$ dical Science, 68, 1097-1100. doi:10.1292/jvms.68.1097

[2] Achkar, S.M., Sinhorini, I.L., Ribeiro, O.G., Carrieri, M.L., Ceretta, R.S. and Consales, C.A. (2007) Immunopathology of rabies infection in mice selected for high or Low acute inflammatory reaction. Journal of Venomous Animals and Toxins including Tropical Diseases, 13, 3955. doi:10.1590/S1678-91992007000100003

[3] Torres, F.D., Valença, C. and Andrade Filho, G.V. (2005) First recordo for Desmodusrotundus in urban área from the city of Olinda, Pernanbuco, northeastern Brazil: A case report. Revista do Instituto de Medicina Tropical de São Paulo, 47, 107-108. doi:10.1590/S0036-46652005000200010

[4] Lima, E.F., Riet-Correa, F., Castro, R.S., Gomes, A.B. and Lima, F.S. (2005) Sinaisclínicos, distribuicão das lesões no sistemanervoso e epidemiologia da raivaem herbívorosnaregiãoNordeste do Brasil. Pesquisa Veterinária Brasileira, 25, 250-264. doi:10.1590/S0100-736X2005000400011

[5] Arthington, J.D., Eichert, S.D., Kunkle, W.E. and Martin, F.G. (2003) Effect of transportation and commingling on the acute-phase protein response, growth, and feed intake of newly weaned beef calves. Journal of Animal Science, 81, 1120-1125.

[6] Reis, L.S.L.S., Chiacchio, S.B., Oba, E., Pardo, P.E. and Frazatti-Gallina, N.M. (2012) Effects of selenium supplementation on serum cortisol in repeatedly handled cattle. Archivos de Zootecnia, 61, 141-144. doi:10.4321/S0004-05922012000100015

[7] Hemsworth, P.H., Coleman, G.J., Barnett, J.L. and Borg, S. (2000) Relationships between human-animal interactions and productivity of commercial dairy cows. Journal 
of Animal Science, 78, 2821-2831.

[8] Hickey, M.C., Drennan, M. and Earley, B. (2003) The effect of abrupt weaning of suckler calves on the plasma concentrations of cortisol, catecholamines, leukocytes, acute-phase proteins and in vitro interferon-gamma production. Journal of Animal Science, 81, 2847-2855.

[9] Borell, E.H. (2001) The biology of stress and its application to livestock housing and transportation assessment. Journal of Animal Science, 79, E260-E267.

[10] Carrasco, G.A. and Van de Kar, L.D. (2003) Neuroendocrine pharmacology of stress. European Journal of Pharmacology, 463, 235-372. doi:10.1016/S0014-2999(03)01285-8

[11] Reis, L.S.L.S., Pardo, P.E. and Oba, E. (2006) Matricariachamomilla $\mathrm{CH}_{12}$ decreases handling stress in Nelore calves. Journal Veterinary Science, 7, 189-192. doi:10.4142/jvs.2006.7.2.189

[12] Blecha, F. (2000) Immune system response to stress. In: Moberg, G.P. and Mench, J.A., Eds., The Biology of Animal Stress: Basic Principle and Implications for Animal Welfare, CABI Publishing, London, 111-146. doi:10.1079/9780851993591.0111

[13] Ciuchini, F., Irsara, A., Pestalozza, S., Di Trani, L. and Antonucci, G. (1981) Rispostaimmunitaria in bovinivaccinaticontro la rabbia con virus attenuatoceppo ERA. Revista di ZootecniaVeterinária, 9, 176-184.

[14] Queiroz da Silva, L.H., Cardoso, T.C., Perri, S.H.V., Pinheiro, D.M. and Carvalho, C. (2003) Pesquisa de anticorpos anti-rábicosembovinosvacinados da região de Araçatuba, SP. Arquivos do InstitutoBiológico, 70, 407-413.

[15] Albas, A., Pardo, P.E., Bremer Neto, H., Gallina, N.M.F., Mourão Fuches, R.M. and Sartori, A. (2005) Vacinação anti-rábicaembovinos: comparação de cincoesquemasvacinais. Arquivos do Instituto Biológico, 72, 153-159.

[16] Giometti1, J., Chiacchio, S.B., Albas, A., Pardo, P.E., Bremer-Neto, H., Giometti, A.I. and Reis, L.S.L.S. (2006) Influência da suplementação com crômionarespostaimunehumoral anti-rábicaembovinos. Arquivos do InstitutoBiológico, 73, 421-427.

[17] Smith, J.S., Yager, P.A. and Baer, G.M. (1996) A rapid fluorescent focus inhibition test (RFFIT) for determing rabies virus-neutralizing antibody. In: Mestin, F.X., Kaplan, M.M. and Koprowski, H., Eds., Laboratory Techniques in Rabies. World Health Organization, Geneva, 181192.

[18] Zalan, E., Wilson, C. and Pukitis, D.A. (1979). A microtest for the quantitation of rabies virus neutralizing antibodies. Journal of Biological Standardization, 7, 213-220. doi:10.1016/S0092-1157(79)80024-4

[19] Banzatto, D.A. and Kronka, S.N. (2006) Experimentaçãoagrícola. FUNEP, Jaboticabal.

[20] Aragón, V.E.F., Graça, D.S., Norte, A.L, Santiago, G.S. and Paula, O.J. (2001) Suplementação com cromo e desempenhoreprodutivo de vacas zebu primíparasmantidas a pasto. Arquivo Brasileiro de Medicina Veterinária e Zootecnia, 53, 624-628. doi:10.1590/S0102-09352001000500019

[21] Vásquez, E.F.A. and Herrera, A.P.N. (2003) Concentra- çãoplasmática de cortisol, uréia, cálcio e fósforoemvacas de cortemantidas a pastosuplementadas com levedura de cromodurante a estação de monta. Ciência Rural, 33, 743-747. doi:10.1590/S0103-84782003000400025

[22] Reis, L.S.L.S., Chiacchio, S.B., Oba, E., Pardo, P.E. and Frazatti-Gallina, N.M.V. (2009) Association between handling stress in the corral and rabies antibody titers in selenium-supplemented cattle. Journal of Venomous Animals and Toxins including Tropical Diseases, 15, 778788. doi:10.1590/S1678-91992009000400015

[23] Andrade, O., Orihuela, A., Solano, J. and Galina, C.S. (2001) Some effects of repeated handling and the use of a mask on stress responses in Zebu cattle during restraint. Applied Animal Behaviour Science, 71, 175-181. doi:10.1016/S0168-1591(00)00177-5

[24] Lensink, B.J., Fernandez, X., Boivin, X., Pradel, P., Le Neindre, P. and Veissier, I. (2000) The impact of gentle contacts on case of handling, welfare, and growth of calves and on quality of veal meat. Journal of Animal Science, 78, 1219-1226.

http://www.journalofanimalscience.org/content/78/5/1219

[25] Moberg, G.P. (2000) Biological response to stress: Implications for animal welfare. In: Moberg, G.P. and Mench, J.A., Eds., The Biology of Animal Stress: Basic Principle and Implications for Animal Welfare, CABI Publishing, London, 1-21. doi:10.1079/9780851993591.0001

[26] Chacón, S.C. and López, H.S. (1994) Es el estrés el quecontrola la respostainmune o viceversa? Veterinaria México, 25, 99-103.

[27] Beníšek, Z., Suli, J., Švrček, Š., Mojžǐšová, J., Takáčová, D., Závadová, J., Ondrejka, R. and Ondrejková, A. (2000) Experimental inactivated purified concentrated adjuvant rabies vaccine. Evaluation of its efficacy in cattle. Acta Veterinaria Brno, 69, 39-44. doi:10.2754/avb200069010039

[28] Rodrigues Da Silva, A.C., Caporale, G.M.M., Gonçalves, C.A., Targueta, M.C., Comin, F., Zanetti, C.R. and Kotait, I. (2000) Antibody response in cattle after vaccination with inactivated and attenuated rabies vaccines. Revista do Instituto de Medicina Tropical de São Paulo, 42, 9598. doi:10.1590/S0036-46652000000200006

[29] Oliveira, N.A., Andrade, M.C.R., Silva, M.V., Moura, W.C. and Contreiras, E.C. (2000) Immune response in cattle vaccinated against rabies. Memórias do Instituto $\mathrm{Os}_{\mathrm{s}}$ waldo Cruz, 95, 83-88. doi:10.1590/S0074-02762000000100013

[30] Reis, L.S.L.S, Frazatti-Gallina, N.M, Paoli, R.L., Giuffrida, R., Albas, A., Oba, E. and Pardo, P.E. (2008) Efficiency of Matricariachamomilla $\mathrm{CH} 12$ and number of doses of rabies vaccine on the humoral immune response in cattle. Journal of Veterinary Science, 9, 433-435. doi:10.4142/jvs.2008.9.4.433

[31] Maria, E.K., Pardo, P.E., Frazatti-Gallina, N.M., Paoli, R.L., Mourão-Fuches, R.M. and Reis, L.S.L.S. (2009) Supplementacão com zinconãoinfluencia a respostaimunehumoralanti-rábicaembovinos. Archivos de Zootecnia, 58, 605-608. 